\title{
PREVALENCE OF SOME BACTERIA YEASTS AND MOLDS IN MEAT FOODS IN SAN LUIS, ARGENTINA
}

\author{
Patricia V. Stagnitta, Blas Micalizzi, Ana M. Stefanini de Guzmán \\ Unit of Microbiology, Department of Biochemistry and Biological Sciences, Faculty of Chemistry, Biochemistry and Pharmacy \\ National University, San Luis, Argentina
}

\begin{abstract}
SUMMARY
In this work we evaluate the microbiological quality and the hygiene degree of meat foods consumed in the city of San Luis. A total of 515 meat food samples (315 from fresh sausages, 100 from hamburgers and 100 from ground beef) were processed, being the most of them non-industrial products. The microbiological quality was determined by counts of total mesophilic bacteria, coliforms, Escherichia coli, molds and yeasts, and Clostridium perfringens. The number of total mesophilic aerobes was within the $10^{6} \mathrm{cfu} / \mathrm{g}$ limit set by the Argentinaan Alimentary Code (AAC). Two hundred seventy six samples exhibited $E$. coli levels between $10^{1}$ and $10^{3} \mathrm{cfu} / \mathrm{g}$. The $58.26 \%$ of the samples with $E$. coli counts above $>10^{1} \mathrm{cfu} / \mathrm{g}$ came from hamburgers and fresh sausages exceeding the AAC limits. Counts of molds and yeasts ranged between $10^{3}$ and $10^{5} \mathrm{cfu} / \mathrm{g}$. From a total of 515 samples, 126 exhibited C. perfringens, out of which $80(64.08 \%)$ gave counts $>10^{2} / \mathrm{g}$, exceeding the limits set by the AAC. Out of these 80 samples, C. perfringens counts were above $10^{5} \mathrm{cfu} / \mathrm{g}$ in 12 of them, and $E$. coli was also detected in 48 samples (38.10\%).

The samples with counts $>10^{5} \mathrm{C}$. perfringens/g are potentially responsible for alimentary intoxication. The results obtained indicate the need to improve the processing and handling conditions of these products.
\end{abstract}

Key words: meat foods, microbiological quality

Adress for correspondence: Ana M. Stefanini de Guzmán, Unit of Microbiology, Department of Biochemistry and Biological Sciences, Faculty of Chemistry, Biochemistry and Pharmacy. National University, Chacabuco y Pedernera, 5700-San Luis, Argentina.

E-mail: pvstag@unsl.edu.ar, blasmi@unsl.edu.ar

\section{INTRODUCTION}

Food safety depends on their adequate manipulation, transportation and storage. Foods are not sterile, in the sense that they normally contain germs - bacteria, viruses, yeasts and molds -, some of which can lead to food intoxication and infections when present in elevated numbers (1).

Particularly susceptible to food infections are children, elderly and immunosupressed individuals. A number of procedures in food industry are applied to guarantee the microbiological safety of foods. Methods such as pasteurization, removal of surface germs by washing, limiting germ growth by cooling, freezing and irradiation, kill some germs and limit the growth of others. Others, such as chemical products are used to control microbial growth.

Meat foods are sometimes contaminated with germs after leaving the manufacture plant. In most cases, contamination is due to inadequate manipulation. Usually, hygiene conditions are poor when foods are produced in non-industrial establishments, mainly due to the fact that the necessary infrastructure for technologically adequate processes is not available.

On the other hand, the quality of foods depends not only on the storage and manipulation conditions, but also on the quality of raw materials $(2,3)$. The wide range of contamination sources leads to the presence of a variety of microorganisms in food, among others, bacteria belonging to the genera Escherichia, Salmonella and Clostridium, in addition to various molds and yeasts that can come from the raw materials or by-cross contamination with man $(4,5)$. Coliforms and $E$. coli are used as contamination markers.

Food quality control as a crucial way to prevent intoxications and infections constitutes a worldwide concern. In spite of the few statistic data available in Argentina, it is known that out of 533 food intoxication cases in the city of Rosario, Santa Fe, during 1990-1999, 26.2\% were children younger 10 years.

In addition, food intoxications exhibited seasonal occurrence, with a $46.4 \%$ of cases in Summer (December-March) and 22.5\% in the warm and cold seasons (May-August). The data from Rosario also indicate that $47.7 \%$ of the cases were symptomless and that $86.2 \%$ of the symptomatic patients exhibited only intestinal symptoms. There was one lethal botulism case in 1991; and there are no records of outbreaks affecting over 20 people (6).

The System for Epidemiological Vigilance recently implemented in Mexico has proved to yield beneficial results. Five food intoxication outbreaks have been recorded. Thirty affected individuals have been identified, distributed in three Sanitary Jurisdictions.

A further advantage of epidemiological vigilance systems is the possibility to identify, prevent and control bacterial food intoxications. During 1996, 5,158 cases were reported while only 1,316 cases were recorded in 2001, indicating a $74.5 \%$ decrease (7).

The purpose of the present investigation was to study the prevalence of some bacteria and yeasts in meat foods, most of them 
from a non-industrial manufacture, widely consumed in the city of San Luis, Argentina, so as to furnish more information that may improve their quality.

\section{MATERIALS AND METHODS}

\section{Samples}

A total of 515 meat food samples purchased in retail stores located in San Luis city were processed (1996-1997). They included 100 hamburger samples, 315 fresh sausage samples, most of them non-industrial manufactures, and 100 samples of ground beef. They were taken to the laboratory and immediately processed or stored at $4-6{ }^{\circ} \mathrm{C}$ for less than $24 \mathrm{~h}$.

\section{Microbiological Analysis}

Meat samples $(2,5 \mathrm{~g})$ were homogenized in mortar with $2.5 \mathrm{~g}$ of fine sand already sterilized in a stove for $1 \mathrm{~h}$ at $180{ }^{\circ} \mathrm{C}$, and then resuspended in $22.5 \mathrm{ml}$ of recently prepared sterile $0.1 \%$ peptone water (1:10 dilution). Then, ten-fold dilutions were made by adding $1 \mathrm{ml}$ of the original suspension to tubes containing $9 \mathrm{ml}$ of $0.1 \%$ sterile peptone water (8). These suspensions were seeded in different culture media under incubation parameters which are shown in Table 1.

Counts of total mesophilic aerobes were done in plate count agar. Only those plates containing between 30 and 300 colonies were considered for the counts. The bacterial count was obtained multiplying the mean number of colonies in three plates by the inverse of the dilution. Results were reported as colony-forming units per gram of food (cfu/g) (9).

The conventional method for counting the coliforms and Escherichia coli utilized lauryl tryptose broth. The broth components were dissolved in distilled water and $10 \mathrm{ml}$ of the medium were placed in assay tubes containing Durham tubes for detecting gas production. Gas formation in the Durham tube was considered positive. For confirmation of Escherichia coli, an aliquot from the tubes that were positive in the above medium was seeded in EC broth (Merck). Tubes with evident gas formation were considered positive. Results were reported as more probable number (MPN) (9).

The investigation of yeasts and molds was carried out in modified dichloran-rose bengal- chlortetracycline agar medium, substituting chlortetracycline with $20,000 \mathrm{UI} / 1$ of penicillin and $40 \mathrm{mg} / \mathrm{l}$ of streptomycin. Results were informed as cfu/g (9).

C. perfringens counts were done in iron-milk medium (10) and tryptose sulfite cycloserine agar (TSCA). One $\mathrm{ml}$ of each dilution was seeded in three tubes containing the iron-milk medium. Those tubes exhibiting stormy fermentation, made evident by acid formation and breakage of the coagulum by gas production due to lactose fermentation, were considered positive (9). Results were presented as MPN, that was determined using Man's Table (11).

Counts and isolation of $C$. perfringens were also carried out in TSCA. The TSCA medium was sterilized in autoclave at $121{ }^{\circ} \mathrm{C}$ for $20 \mathrm{~min}$ and D-cycloserine solution (Sigma) at a $500 \mathrm{mg} / \mathrm{ml}$ final concentration was added immediately before use (12). Different dilutions of the samples were surface streaked in duplicate. The anaerobic conditions for incubation were obtained by evacuation replacement with propane-butane. Those plates containing
Table 1. Culture media, incubation times and temperatures for microbiological analysis

\begin{tabular}{|l|l|c|c|}
\hline \multirow{2}{*}{ Microbial group } & \multirow{2}{*}{ Culture medium } & \multicolumn{2}{|c|}{ Incubation } \\
\cline { 3 - 4 } Total aerobic counts & plate counts agar & $37^{\circ} \mathrm{C}$ & $48 \mathrm{~h}$ \\
\hline Total coliforms & lauryl tryptose broth & $37^{\circ} \mathrm{C}$ & $48 \mathrm{~h}$ \\
\hline Fecal coliforms & EC broth & $45^{\circ} \mathrm{C}$ & $24 \mathrm{~h}$ \\
\hline Yeast and moulds & $\begin{array}{l}\text { modified dichloran rose } \\
\text { bengal } \\
\text { chlortetracycline agar }\end{array}$ & $20-24^{\circ} \mathrm{C}$ & $3-5$ days \\
\hline $\begin{array}{l}\text { C. perfringens } \\
\text { counts }\end{array}$ & iron-milk & $45^{\circ} \mathrm{C}$ & $16-18 \mathrm{~h}$ \\
\hline & TSCA & $35^{\circ} \mathrm{C}$ & $48 \mathrm{~h}$ \\
\hline
\end{tabular}

between 30 and 300 black colonies were considered for the count. Results were informed as cfu/g. Black $C$. perfringens colonies were due to the reduction of sulfite to sulfide and the formation of iron sulfide.

The isolated strains were purified by seeding on TSCA or by keeping them in cooked meat medium. The identification of suspected colonies was carried out by using the conventional tests $(13,14)$.

\section{RESULTS}

The prevalence of different microbial groups in meat foods is shown in Table 2 .

\section{Count of Total Mesophilic Aerobe Bacteria}

Total mesophilic aerobe counts in the 515 samples ranged between $10^{3}$ and $10^{6} \mathrm{cfu} / \mathrm{g}$, within the $10^{6} / \mathrm{g}$ limit accepted by the Argentina Alimentary Code (AAC) for mesophilic bacteria (15).

\section{Count of Total Coliforms and $E$. coli}

The counts of total coliforms in the 515 samples ranged between $10^{1}$ and $10^{3} \mathrm{cfu} / \mathrm{g}$.

Out of the 515 samples, the counts of $E$. coli in 276 samples ranged between $10^{1}$ and $10^{3} \mathrm{cfu} / \mathrm{g}$, the $58,26 \%$ of them exceeding the limit established by the AAC for enterobacteria ( 10 bacteria/g) (15).

\section{Counts of Molds and Yeasts}

The counts of molds and yeasts in the 515 samples were $10^{3}-10^{5} \mathrm{cfu} / \mathrm{g}$. The AAC (15) establishes no regulation for these microorganisms. 
Table 2. Prevalence of different microbial groups in meat foods

\begin{tabular}{|l|c|c|c|c|c|c|}
\hline \multicolumn{1}{|c|}{ Meat food } & No. of samples & $\begin{array}{c}\text { Total mesophilic } \\
\text { aerobes (\%) }\end{array}$ & $\begin{array}{c}\text { Total coliforms } \\
\text { (\%) }\end{array}$ & E. coli (\%) & $\begin{array}{c}\text { Yeast and molds } \\
\text { (\%) }\end{array}$ & $\begin{array}{c}\text { C. perfringens } \\
\text { (\%) }\end{array}$ \\
\hline Fresh sausages & 315 & 100 & 100 & 62.20 & 100 & 26.35 \\
\hline Hamburgers & 100 & 100 & 100 & 56.00 & 100 & 19.00 \\
\hline Ground beef & 100 & 100 & 100 & 24.00 & 100 & 24.00 \\
\hline
\end{tabular}

\section{C. perfringens Counts and Isolation}

A total of $126 C$. perfringens strains were isolated and identified in the 515 samples. Twelve samples $(9.52 \%)$ gave counts $>10^{5}$ microorganisms $/ \mathrm{g}$ by the MPN method. Of the 126 samples with $C$. perfringens isolations, 48 (38.1\%) exhibited a MPN value of $C$. perfringens $>10^{2}$, above the limit accepted by the AAC (up to $10^{2}$ sporulated anaerobes $\left./ \mathrm{g}\right)(15)$.

\section{C. perfringens Phenotyping}

The isolated strains exhibited the following $C$. perfringens phenotypical characteristics: grampositive, nonmotility, catalase-negative, lecithinase-positive, hemolytic, and positive for the CAMP reverse test. Also, they reduced the nitrates and hydrolyzed gelatin and starch (14).

\section{DISCUSSION}

The evaluation of certain microbial groups can be a good indicator of the microbiological quality of meat foods. In particular, mesophilic aerobe flora has been used as a criterion to predict the mean life of a product. These microorganisms can be used as indicators of inadequate product manufacturing and/or handling. The microbial levels present in the raw meat food can increase during processing, cutting, transportation and storage (16). In our study, most of the samples analyzed were from nonindustrial origin. Even though high contamination levels with mesophilic aerobes have been reported for meat foods (17), the total mesophilic aerobe counts found in this work were below the $10^{6} \mathrm{cfu} / \mathrm{g}$ limit established by the AAC (15). The short life of meat limits the possibility of fungal contamination, however, molds and yeasts are widely distributed in the environment and can easily reach the meat product through contaminated equipment or air, thus leading to alterations of the meat product that can provoke infections or allergic reactions. As the AAC (15) does not establish safety limits for molds and yeasts, it cannot be stated whether the values obtained here $\left(10^{3}-10^{5} \mathrm{cfu} / \mathrm{g}\right)$ imply a risk to human health.

Most of the enterobacteria present in meat come from faecal contamination. Elevated numbers of enterobacteria can be an indicator of poor hygienic conditions during handling or inadequate storing (18-27). Counts of E.coli that exceed the limits established by regulations have been frequently reported throughout the world. In a study of meat foods carried out in Johannesburg, over $90 \%$ of the samples were found to be contaminated with $E$. coli, with values above $10^{3} \mathrm{cfu} / \mathrm{g}$ in $18 \%$ of the samples (17). In Australia, counts above $10^{6} \mathrm{cfu} / \mathrm{g}$ have been reported for meat foods (27). In this work, a high percentage $(58.26 \%)$ of samples were found to have counts of total coliforms and E. coli above $10^{2} \mathrm{cfu} / \mathrm{g}$, mostly in hamburgers and fresh sausages. This result strongly suggests the need to improve hygienic conditions in the manufacturing of these products. It is also recommended that consumers should eat these products well-cooked.

Numerous studies have tried to determine the microbiological quality of meats by means of $C$. perfringens investigation (3, 4, 28-31).

Out of the 214 outbreaks reported in Australia (1995-2000), bacterial disease was responsible for $61 \%$ of outbreaks. The most frequently implicated vehicles were meats. $C$. perfringens was the aetiological agent in $14 \%$ of the cases (32). Many meat-based foods are cooked at temperatures high enough to inactivate vegetative cells of $C$. perfringens, but spores of this bacterium can survive, germinate, and grow in these products whenever adequate time, temperature, and other variables concur. Because ingestion of large numbers of vegetative cells can lead to concomitant sporulation, enterotoxin release in the gastrointestinal tract, and diarrhea-like illness, it becomes necessary a food safety objective so as to ensure that the levels of $C$. perfringens present in finished products are within the limits established (33).

In this study, counts above $10^{5} \mathrm{C}$. perfringens/g were obtained in 12 (one from hamburger and the remaining ones from fresh sausages) of the $126 \mathrm{C}$. perfringens positive samples, indicating a potential hazard of alimentary intoxication (5). In addition, $64.08 \%$ of 126 samples with $C$. perfringens counts $>10^{2} \mathrm{MPN} / \mathrm{g}$ also presented $E$. coli, suggesting that the poor sanitary condition of the samples may be associated with the presence of $C$. perfringens. The highest $E$. coli and $C$. perfringens counts were obtained in fresh sausage samples, probably due to the fact that this food includes a number of different ingredients and is exposed to much more manipulation. In a study carried out in Venezuela, on seafood, it was found that the levels of $E$. coli and $C$. perfringens in the products after handling duplicated the values obtained during collection (34). Similarly, high levels of E. coli, C. perfringens, Staphylococcus aureus and Pseudomonas aeruginosa were detected in samples of meat foods studied in Spain. Raw materials and food handlers were the principal sources of microbial contamination (2). From the results here obtained, it can be concluded that fresh sausage bring about the highest risk of intoxication, followed by ground beef and hamburgers.

High microbiological quality is associated with premises where the personal is trained in food hygiene and those that had hazard analysis in place.

In contrast, low microbiological quality is associated with storage above $8{ }^{\circ} \mathrm{C}$, presliced meats, infrequent cleaning of slicing equipments and poor control of practices that likely lead to cross contamination (35). 
Personal hygiene precautions can prevent traveler's diarrhea, but poor restaurant hygiene in most developing countries continues to create an insurmountable risk of acquiring traveler's diarrhea (36). The effectiveness of food hygiene training for groups of retail butchers and supervision of activities may be necessary to maintain behavioral changes (37).

This study provides very usefull information about the microbiological quality of some meat foods consumed in San Luis, Argentina, and could help caterers, retailers, enforcement officers and policy retailers understand the role played by food safety practices on the microbiological quality of food.

\section{Acknowledgments}

This work was supported by Secretaría de Ciencia y Técnica - Universidad Nacional de San Luis. Research Project 8803. The authors wish to thank to Dr. María Esther Escudero for the reading of the manuscript.

\section{REFERENCES}

1. Food infections and intoxications from microbiological origin. In: Frazier WC, Westhoff DC. Food Microbiology. $3^{\text {rd }}$ ed. Zaragoza: Editorial Acribia S.A; 1978. p. 413. (In Spanish.)

2. Cordoba MG, Cordoba JJ, Jordano R. Evaluation of microbial hazards during processing of Spanish prepared Flamenquin. J Food Prot. 1998 Jun;61(6):693-9.

3. Emswiler BS, Pierson CJ, Kotula AW. Bacteriological quality and shelf life of ground beef. Appl Environ Microbiol. 1976 Jun;31(6):826-30.

4. Sackey BA, Mensah P, Collison E, Sakyi-Dawson E. Campylobacter, Salmonella, Shigella and Escherichia coli in live and dressed poultry from metropolitan accra. Int J Food Microbiol. 2001 Dec 4;71(1):21-8.

5. Clostridium perfringens. In: Smith LDS, Williams BL. The pathogenic anaerobic bacteria. $3^{\text {rd }}$ ed. Sprinfield, USA: Charles C. Thomas Publishers; 1984. p. 101-136.

6. Piola JC, Cagna B, Prada DB, Evangelista M. Food poisoning in Rosario, 1990-99. In: XII Argentina Congress of Toxicology; 2001 Sep 25-27; Rosario, Argentina.

7. Laurell Asa C. Report to the supply commission and distribution of foods II, Legislative Assembly. Mexico: Secretary of Health of the Federal Dictrict; 2002. (In Spanish.)

8. Stagnitta PV, Micalizzi B, Stefanini de Guzmán AM. Prevalence of enterotoxigenic Clostridium perfringens in meats in San Luis, Argentina. Anaerobe. 2002 Oct;8(5):253-8.

9. Feng P, Weagant SD, Grant MA. Chapter 4. Enumeration of Escherichia coli and the Coliform Bacteria. In: Bacteriological Analytical Manual. Food and Drug Administration. 8th Edition, Revision A. [monograph on the Internet]. Gaithersburg: AOAC International; 1998 [cited $2006 \mathrm{Mar}$ 23]. Available from: http://www.cfsan.fda.gov/ ebam/bam-4.html.

10. William DSTJ, Matches JR, Wekell MM. Use of iron milk medium for enumeration of Clostridium perfringens. J Assoc Off Anal Chem. 1982;65(5):1129-33.

11. de Man JC. Most Probable Number tables, corrected. Eur J Appl Biotechnol. 1983;17: 301-5.

12. Neut C, Pathak J, Romond C, Beerens H. Rapid detection of Clostridium perfringens: comparison of lactose sulfite broth with tryptose-sulfitecycloserine agar. J Assoc Off Anal Chem. 1985 Sep-Oct;68(5):881-3.

13. Buchanan AG. Clinical laboratory evaluation of a reverse CAMP test for presumptive identification of Clostridium perfringens. J Clin Microbiol. 1982 Oct;16(4):761-2.

14. Cato EP, George WL, Finegold SM. Genus Clostridium. In: Sneath PHA, Mair NS, Sharpe ME, Holt JG, editors. Bergey's manual of systematic bacteriology. Baltimore: Williams \& Wilkins; 1986. p. 1141-1200.

15. De la Canal JJ. Meat foods and similar ones. Chapter VI. Art. 255 bis. [code of law on Internet]. De la Canal \& Asociados SRL; c2004 [cited 2006 Mar 23]. Available from: www.anmat.gov.ar/codigo/caal.htm. (In Spanish.)
16. Alonso-Calleja C, Martínez-Fernández B, Prieto M, Capita R. Microbiological quality of vacuum-packed retail ostrich meat in Spain. Food Microbiol. 2004 Apr;21(2):241-6.

17. Meara PJ, Melmed LN, Cook RC. Microbiological investigation of meat wholesale premises and beef carcases in Johannesburg. J S Afr Vet Assoc. 1977 Dec;48(4):255-60.

18. Du WX, Huang T, Kim J, Marshall MR, Wei C. Chemical, microbiological, and AromaScan evaluation of mahi-mahi fillets under various storage conditions. J Agric Food Chem. 2001 Jan;49(1):527-34.

19. Gillespie I, Little C, Mitchell R. Microbiological examination of cold readyto-eat sliced meats from catering establishments in the United Kingdom. J Appl Microbiol. 2000 Mar;88(3):467-74.

20. Hansson IB. Microbiological meat quality in high- and low-capacity slaughterhouses in Sweden. J Food Prot. 2001 Jun;64(6):820-5.

21. Heredia N, Garcia S, Rojas G, Salazar L. Microbiological condition of ground meat retailed in Monterrey, Mexico. J Food Prot. 2001 Aug;64(8):1249-51.

22. Mosupye FM, von Holy A. Microbiological hazard identification and exposure assessment of street food vending in Johannesburg, South Africa. Int J Food Microbiol. 2000 Nov 1; 61(2-3):137-45.

23. Murray KA, Gilmour A, Madden RH. Microbiological quality of chilled beef carcasses in Northern Ireland: a baseline survey. J Food Prot. 2001 Apr;64(4):498-502.

24. Phillips D, Sumner J, Alexander JF, Dutton KM. Microbiological quality of Australian beef. J Food Prot. 2001 May;64(5):692-6.

25. Phillips D, Sumner J, Alexander JF, Dutton KM. Microbiological quality of Australian sheep meat. J Food Prot. 2001 May;64(5):697-700.

26. Soriano JM, Rico H, Molto JC, Manes J. Microbial evaluation of Spanish potato omelette and cooked meat samples in University restaurants. J Food Prot. 2000 Sep;63(9):1273-6.

27. Vanderlinde PB, Shay B, Murray J. Microbiological quality of Australian beef carcass meat and frozen bulk packed beef. J Food Prot. 1998 Apr; 61(4):437-43.

28. Capita R, Alonso-Calleja C, Garcia-Fernandez MD, Moreno B. Microbiological quality of retail poultry carcasses in Spain. J Food Prot. 2001 Dec;64(12):1961-6.

29. Gill CO, Penney N, Nottingham PM. Effect of delayed evisceration on the microbial quality of meat. Appl Environ Microbiol. 1976 Apr; 31(4): 465-8.

30. Little CL, Gillespie IA, Mitchell RT; Local Authority Co-ordinating body on Food and Trading Standards; Public Health Laboratory Service. Microbiological examination of ready-to-eat burgers sampled anonymously at the point of sale in the United Kingdom. Commun Dis Public Health. 2001 Dec;4(4):293-9.

31. Roberts TA, Britton CR, Hudson WR. The bacteriological quality of minced beef in the U.K. J Hyg (Lond). 1980 Oct;85(2):211-7.

32. Dalton CB, Gregory J, Kirk MD, Stafford RJ, Givney R, Kraa E, Gould D. Foodborne disease outbreaks in Australia, 1995 to 2000. Commun Dis Intell. 2004;28(2):211-24.

33. Taormina PJ, Dorsa WJ. Growth potential of Clostridium perfringens during cooling of cooked meats. J Food Prot. 2004 Jul;67(7):1537-47.

34. Villalobos de Bastardo LB, Elguezabal Aristizabal L. Microbiological quality of the bivalve Pinctada imbricata commercialized in Cumana, Venezuela. Acta Cient Venez. 2001;52(1):55-61.

35. Elson R, Burgess F, Little CL, Mitchell RT; Local Authorities Co-Ordinators of Regulatory Services and the Health Protection Agency. Microbiological examination of ready-to-eat cold sliced meats and pate from catering and retail premises in the UK. J Appl Microbiol. 2004; 96(3):499-509.

36. Shlim DR. Looking for evidence that personal hygiene precautions prevent traveler's diarrhea. Clin Infect Dis. 2005 Dec 1;41 Suppl 8:S531-5

37. Vaz ML, Novo NF, Sigulem DM, Morais TB. A training course on food hygiene for butchers: measuring its effectiveness throug microbiological analysis and the use of an inspection checklist. J Food Prot. 2005 Nov;68(11):2439-42. 